Article

\title{
Drought-Modulated Boreal Forest Fire Occurrence and Linkage with La Nina Events in Altai Mountains, Northwest China
}

\author{
Chunming Shi ${ }^{1} \mathbb{D}$, Ying Liang ${ }^{2, *}$, Cong Gao ${ }^{1}$, Qiuhua Wang ${ }^{3} \mathbb{D}$ and Lifu Shu ${ }^{4, *}$ \\ 1 College of Global Change and Earth System Science, Beijing Normal University, Beijing 100875, China; \\ chunming.shi@gmail.com (C.S.); gaocong@mail.bnu.edu.cn (C.G.) \\ 2 Xinjiang Academy of Forestry Sciences, Urumqi 830000, China \\ 3 College of Civil Engineering, Southwest Forestry University, Kunming 650224, China; \\ qhwang2010@swfu.edu.cn \\ 4 Research Institute of Forest Ecology, Environment and Protection, Chinese Academy of Forestry, \\ Forest Protection Laboratory of National Forestry and Grassland Administration, Beijing 100091, China \\ * Correspondence: liangyin0421@126.com (Y.L.); slfhxk@126.com (L.S.)
}

Received: 28 July 2020; Accepted: 4 September 2020; Published: 7 September 2020

\begin{abstract}
Warming-induced drought stress and El Nino-associated summer precipitation failure are responsible for increased forest fire intensities of tropical and temperate forests in Asia and Australia. However, both effects are unclear for boreal forests, the largest biome and carbon stock over land. Here, we combined fire frequency, burned area, and climate data in the Altai boreal forests, the southmost extension of Siberia's boreal forest into China, and explored their link with El Nino-Southern Oscillation (ENSO). Surprisingly, both summer drought severity and fire occurrence showed significant $(p<0.05)$ correlation with La Nina events of the previous year and therefore provide an important reference for forest fire prediction and prevention in Altai. Despite a significant warming trend, the increased moisture over Altai has largely offset the effect of warming-induced drought stress and led to an insignificant fire frequency trend in the last decades, resulting in largely reduced burned area since the 1980s. The reduced burned area can also be attributed to fire suppression efforts and greatly increased investment in fire prevention since 1987.
\end{abstract}

Keywords: boreal forest; forest fire; ENSO; Altai Mountain

\section{Introduction}

Climate warming is faster at higher latitudes and altitudes [1-3]. Boreal forest, the largest biome and living carbon stock on land, has therefore experienced a faster warming rate than the global mean level and an unprecedented large fire disturbance over the past 10,000 years [4,5], mainly due to increased lighting ignition in association with warming [6-9], fire season extension [10,11], and higher fuel aridity with better fuel composition [12,13]. Forest fires play a key role in dominating the structure, succession, and function of boreal forests $[14,15]$ and release a large amount of organic carbon into the atmosphere, potentially transforming boreal forests from net carbon sink to net source $[16,17]$. The $\mathrm{CO}_{2}$, black carbon, and aerosols emitted from forest fires have aggravated global warming [18], which in turn has increased the fire risk $[19,20]$. Although great anthropogenic suppression efforts have been taken globally, the observed and projected forest fire intensity is still increasing significantly over the globe in the 21st century [21-24].

Superimposed on the increasing trend of warming-induced forest fires, internal variabilities inherent in the climate system have modulated the fire regime at interannual to decadal timescales. For instance, El Nino-Southern Oscillation (ENSO), shifting between warm (El Nino) and cold (La Nina) 
phases, is considered as one of the main sources of interannual climate variabilities. Pacific Decadal Oscillation (PDO), a climate variability shift at an interdecadal timescale, modulates ENSO's impacts through in-phase (overlapping) or out-phase (counteract) with ENSO [25-27]. Both ENSO and PDO are closely teleconnected with precipitations, temperature, and drought severity [28-33]. Therefore, ENSO and PDO modulate forest fire occurrence over a large part of the Asian and American continents [24]. The frequency of extreme El Nino and La Nina events are projected to increase with global warming [34-36], substantially elevating future forest fire risk.

The effects of ENSO and PDO on forest fire variability have been widely explored for tropical and temperate forests, For example, the combination of cold ENSO (La Nina) and PDO phases was found to be closely related to anomalous high fire occurrence in the west coast forests of North America [37-39]. In contrast, the dry condition in association with warm ENSO (El Nino) and PDO phases have led to significantly increased forest fire intensity in most of China [40], southeast Asia [41], central to eastern America [24,42,43], southeast Australia [44,45], and tropical rain forests [46]. A warm ENSO-warm PDO combination has greatly increased the fire risk, frequency, and burned area in the boreal forests in North America and Northeast China [26,47-50] as well as wildfire emissions in the northern high latitudes [51]. However, the impacts of ENSO and PDO on boreal forest fires in nonmonsoonal regions, especially in inland Asia, is still unclear. The connection of La Nina events with high fire risk of boreal forests has not been found.

In this study, we constructed a dataset combining fire frequency and burned areas of the boreal forest in Northwest China. The linkage of fire data with ENSO and long-term climate trends and the teleconnection between local climate and ENSO were explored as well.

\section{Data and Method}

\subsection{Study Region}

This study focused on forest fires in the Altai Prefecture of Xinjiang Province, China, the most northwest corner of China (gray area in the top left insert of Figure 1). This area is adjacent to three countries: Mongolia, Russia, and Kazakhstan. The boreal forest in the study region is the southmost extension of Siberia's boreal forest into China. The main species are Picea obovate, Abies sibirica, Larix sibirica Ledeb, and Pinus sibirica (Loud.) Mayr. The annual mean temperature and total precipitation are $2.4{ }^{\circ} \mathrm{C}$ and $200.4 \mathrm{~mm}$, respectively, and $62.5 \%$ of precipitation falls in May-September (defined here as summer), when almost all forest fires occur.

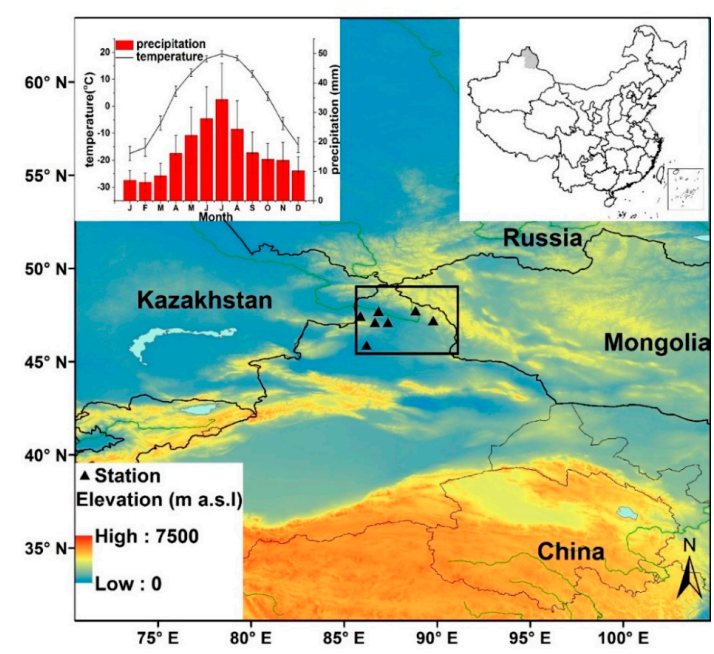

Figure 1. Meteorological stations are indicated with black triangles. Gray shading of the top right insert shows the Altai Prefecture. The black rectangle is the study area $\left(45-49^{\circ} \mathrm{N}, 85-91^{\circ} \mathrm{E}\right)$. The top left insert is the Walter-Lieth diagram of the study region; the temperature (black curve) and precipitation (red bars) are the regional averaged data of CRU TS4.03 dataset. 


\subsection{Fire and Climate Data}

The large snow cover before May and after September largely suppresses fire occurrence. Therefore, May-September fire numbers and burned area data spanning 1960-2018 were obtained from individual forest administrations of seven counties of Altai and were then averaged to represent the mean fire frequency of Altai Prefecture. Monthly climate data of $0.5^{\circ}$ resolution, including temperature, precipitation, and self-calibrating Palmer Drought Severity Index (scPDSI), were extracted from the Climate Research Unit (CRU) TS 4.03 dataset and averaged over a rectangle of $45-49^{\circ} \mathrm{N}, 85-91^{\circ} \mathrm{E}$ to estimate the mean climate condition of Altai. The one-month Standardized Precipitation-Evapotranspiration Index (SPEI1) and monthly relative humidity (RH) data (black triangles in Figure 1) were downloaded from the Spanish National Research Council (CSIC) and meteorological stations of the seven counties, respectively. Monthly NINO3 (NINO sea surface temperature (SST) index in region $5 \mathrm{~N}-5 \mathrm{~S}, 150 \mathrm{~W}-90 \mathrm{~W}$ ) and PDO indices derived from ERSST v5 datasets were obtained from KNMI climate explorer (http://climexp.knmi.nl/). Then, the monthly NINO3 showing significant correlation with May-September fire occurrence was combined for future analysis.

The years with fire occurrence and SPEI1 above and below the 95\% distribution limits were defined as the years of most frequent fire and drought stress, respectively. The coincidence of the extreme years was tested. In order to explore the connection of drought severity and fire occurrence, Pearson's correlation coefficients were calculated between fire frequency and moisture indicators. Two-tailed null hypothesis test was used to calculate the significance levels of the correlations. Monthly NINO3 and PDO data were correlated to summer fire frequency to determine the key season of teleconnection and possible time lag effect. The same analysis between key season NINO3 and summer moisture indices was conducted to explore the mechanisms underlining the teleconnection.

\section{Results}

\subsection{Linkage of Fire and Moisture Variability}

The mean correlation coefficient of the summer fire number among the seven counties reached 0.49 (1960-2018, Figure A1), suggesting a synchronous variation of fire occurrence and reasonable pooling of these data. The six years with the most frequent fire occurrence (Year-f, red stars in Figure 2A) and the largest drought stress (Year-d, blue stars in Figure 2A) were identified. We found four out of six Year-f (1962, 1963, 1974, and 1982) and two years with the largest burned areas (1962 and 1974) coincided with Year-d. Four out of six Year-f occurred before 1987, after which a great fire suppression effort has been carried out in China. The $R$ between summer fire frequency and SPEI1 reached 0.46 (1960-2018, $p<0.001)$, showing the possible link between drought severity and fire occurrence. The trend of fire frequency was insignificant (1960-2018, slope $=0.45 \pm 1.45 /$ year, $p=0.55)$. Exceptionally large burned areas were recorded in 1962 and 1974 (4.6 and $18.1 \times 103 \mathrm{hm}^{2}$, respectively), which coincided with the two driest years over 1960-2018 (lowest SPEI values in 1962 and 1974). The burned area had never exceeded $3 \times 10^{3}$ ha since the 1980s. Even with comparable drought condition and fire frequency in 2008, the burned area did not reach similar level of 1962 and 1974.

The negative correlation between summer fire frequency and moisture indices, including precipitation, SPEI1, scPDSI, and relative humidity, were all significant above the 95\% level (Figure $3 R=-0.42,-0.46,-0.26$, and $-0.45 ; p<0.01,0.01,0.05$, and 0.01, respectively), suggesting a drought-induced fire occurrence in the Altai region. A significant correlation was not found for fire frequency and temperature records, regardless of minimum, mean, or maximum temperatures. 


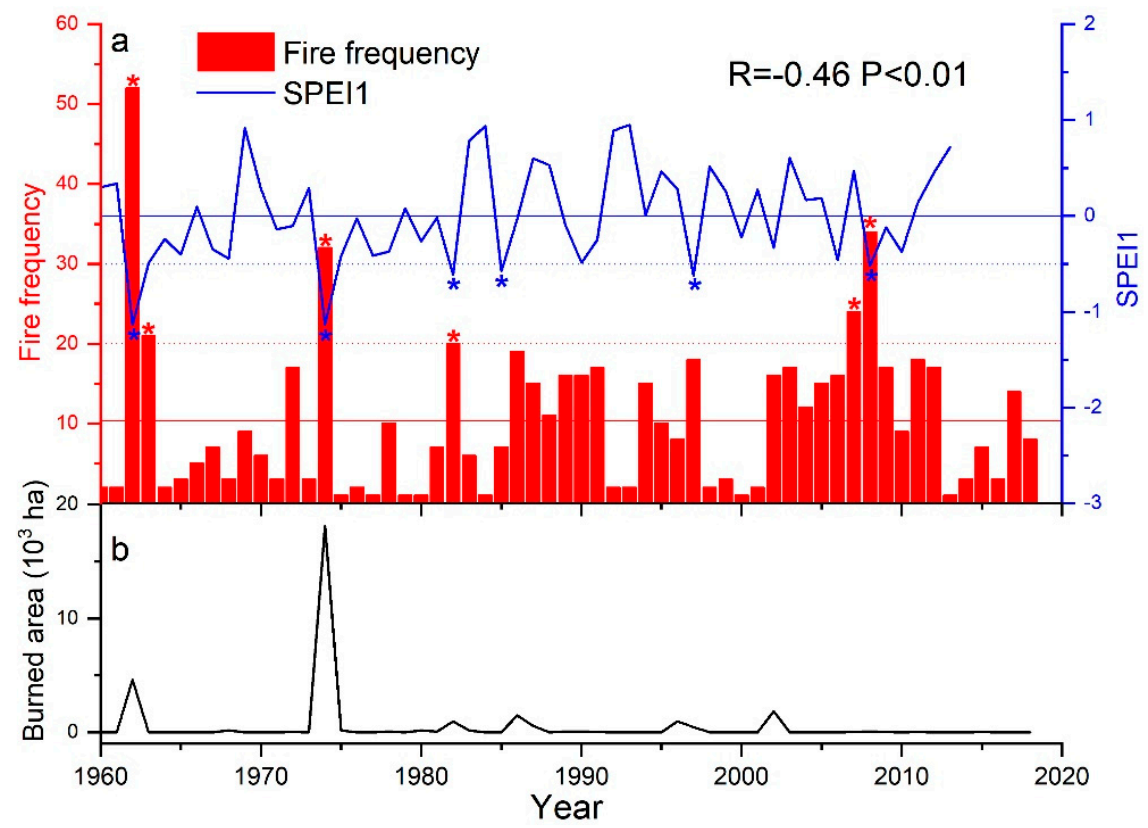

Figure 2. (a) Summer (May-September) fire frequency (red column) and Standardized PrecipitationEvapotranspiration Index (SPEI1; solid blue line). The horizontal solid lines are the mean values, and the dashed red and blue lines indicate the limits of $95 \%$ significant deviation from the mean value. The Extreme frequent fire and dry years are defined as above and below these limits and marked by red and blue stars, respectively. (b) Annual summer burned area.
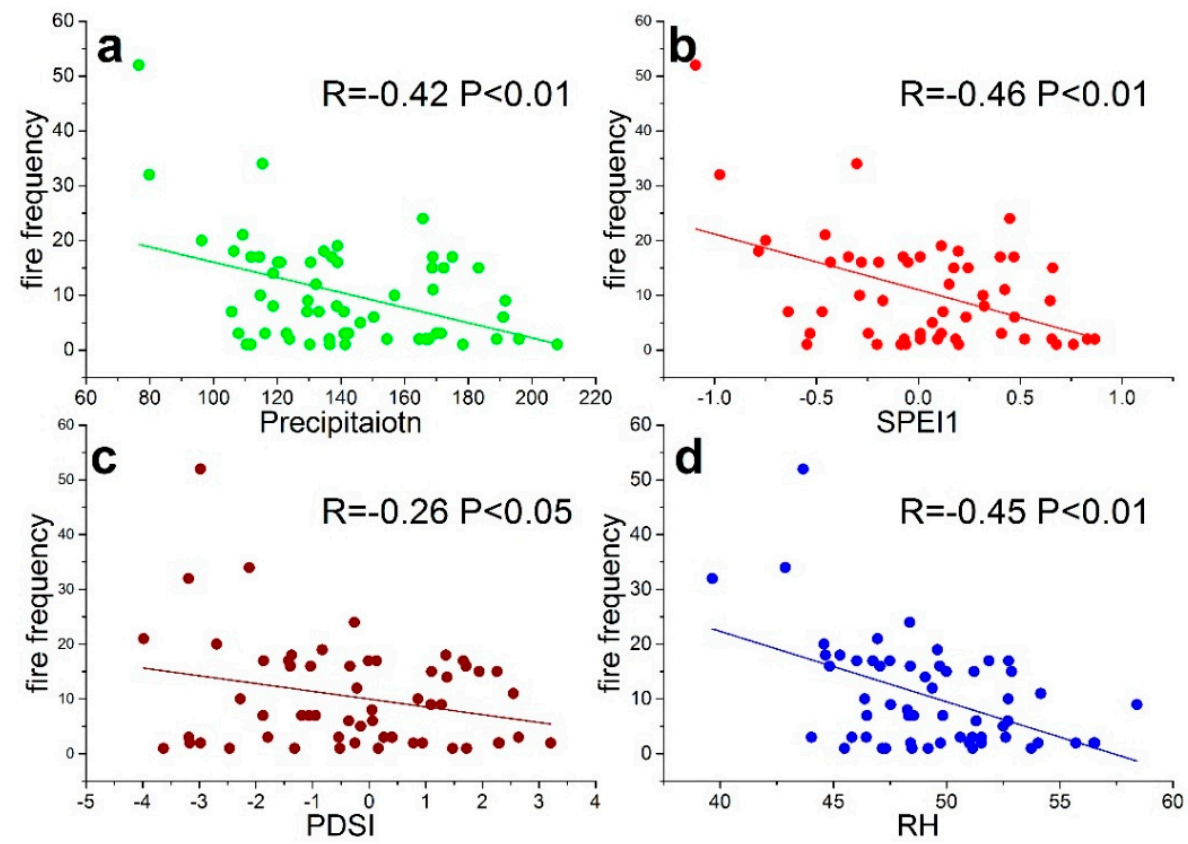

Figure 3. Scatter plot with correlation coefficients between summer fire frequency and moisture variability of the study region: (a) precipitation; (b) SPEI1; (c) Palmer Drought tableSeverity Index (scPDSI); (d) relative humidity $(\mathrm{RH})$.

\subsection{Teleconnection of ENSO/PDO and Local Moisture Variabilities}

Figure 4 shows the July-October NINO3 and October-November PDO of the previous year were significantly $(p<0.05)$ and negatively correlated with fire frequency of the current summer. Although insignificant, the correlation coefficients were all negative from the previous December to 
the current May. All these results imply a persistent teleconnection between previous SST of the eastern tropical Pacific Ocean and summer Altai fire and climate variabilities.

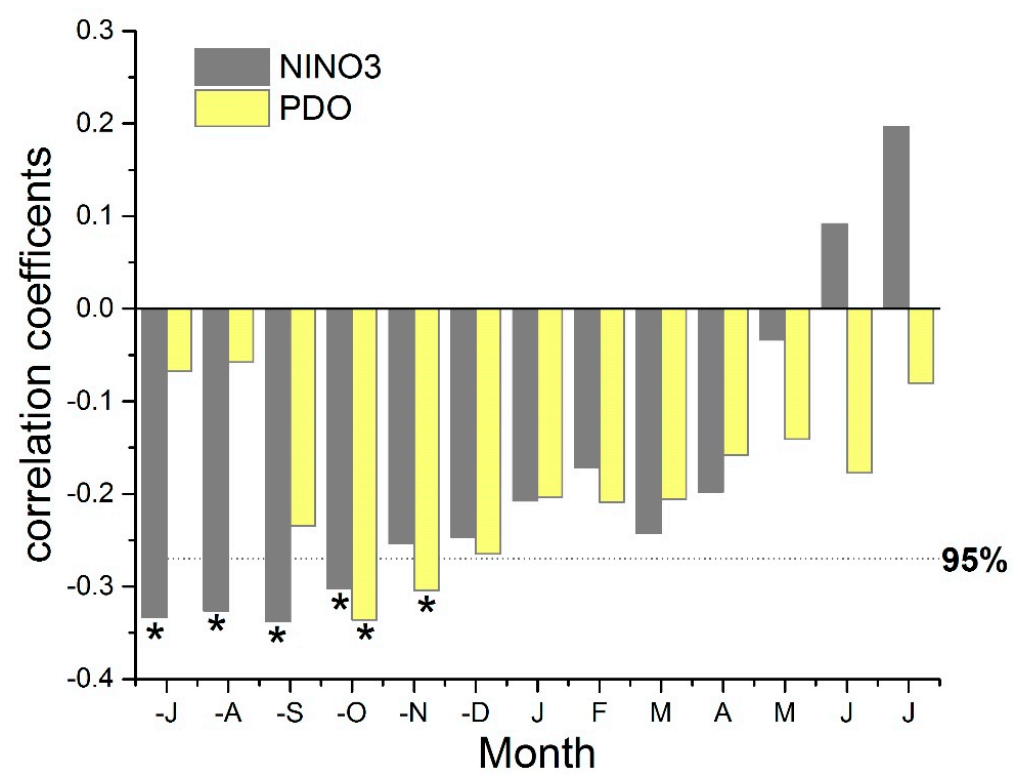

Figure 4. Correlation coefficients of monthly NINO3/ Pacific Decadal Oscillation (PDO) and summer fire frequency from July of the previous year to July of the current year (1960-2018); horizontal dashed line is the $95 \%$ significance level, results exceeding $95 \%$ significance level were donated with stars.

To understand the mechanisms underlying the teleconnection between ENSO and local climate, correlation analysis of NINO3 and moisture indices was conducted and are presented in Figure 5. All the four moisture indices showed significantly positive $R$ with NINO3 index $(R=0.45,0.42$, 0.33 , and $0.41 ; p<0.01,0.01,0.05$, and 0.01 for precipitation, SPEI1, scPDSI, and RH, respectively), suggesting that a previous El Nino event might have led to high summer moisture availability in Altai, and vice versa. The spatial correlation between the July-October NINO3 index of the previous year and summer precipitation, SPEI1, and scPDSI were all significant $(p<0.05)$ over the study region (Figure 6a-c). In addition, summer Altai RH showed significant coherence $(p<0.05)$ with previous July-October SST over the eastern tropical Pacific Ocean (Figure 6d), where the SST anomalies define the NINO3 index.

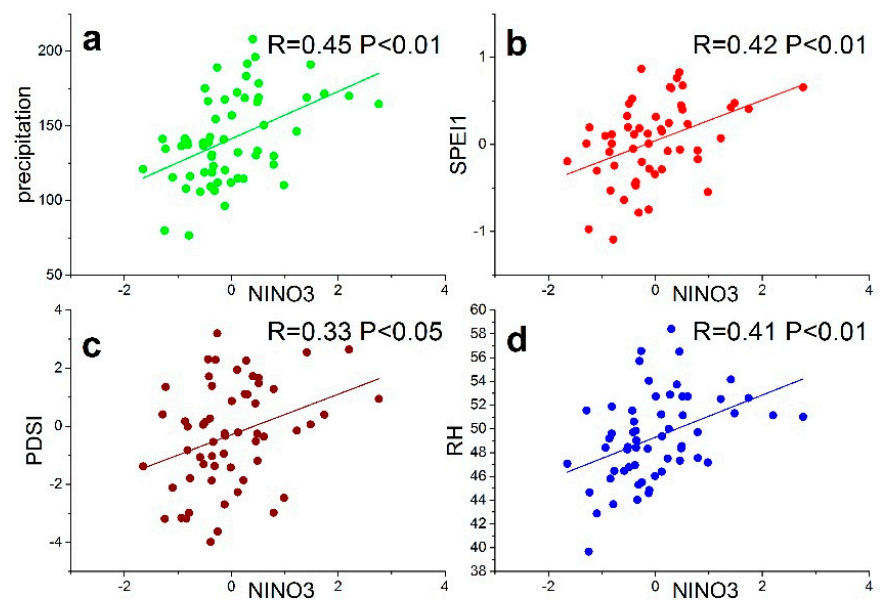

Figure 5. Scatter plot with correlation coefficients between NINO3 average over July-October of the previous year and summer moisture variability of the current year: (a) precipitation; (b) SPEI1; (c) scPDSI; (d) relative humidity. 

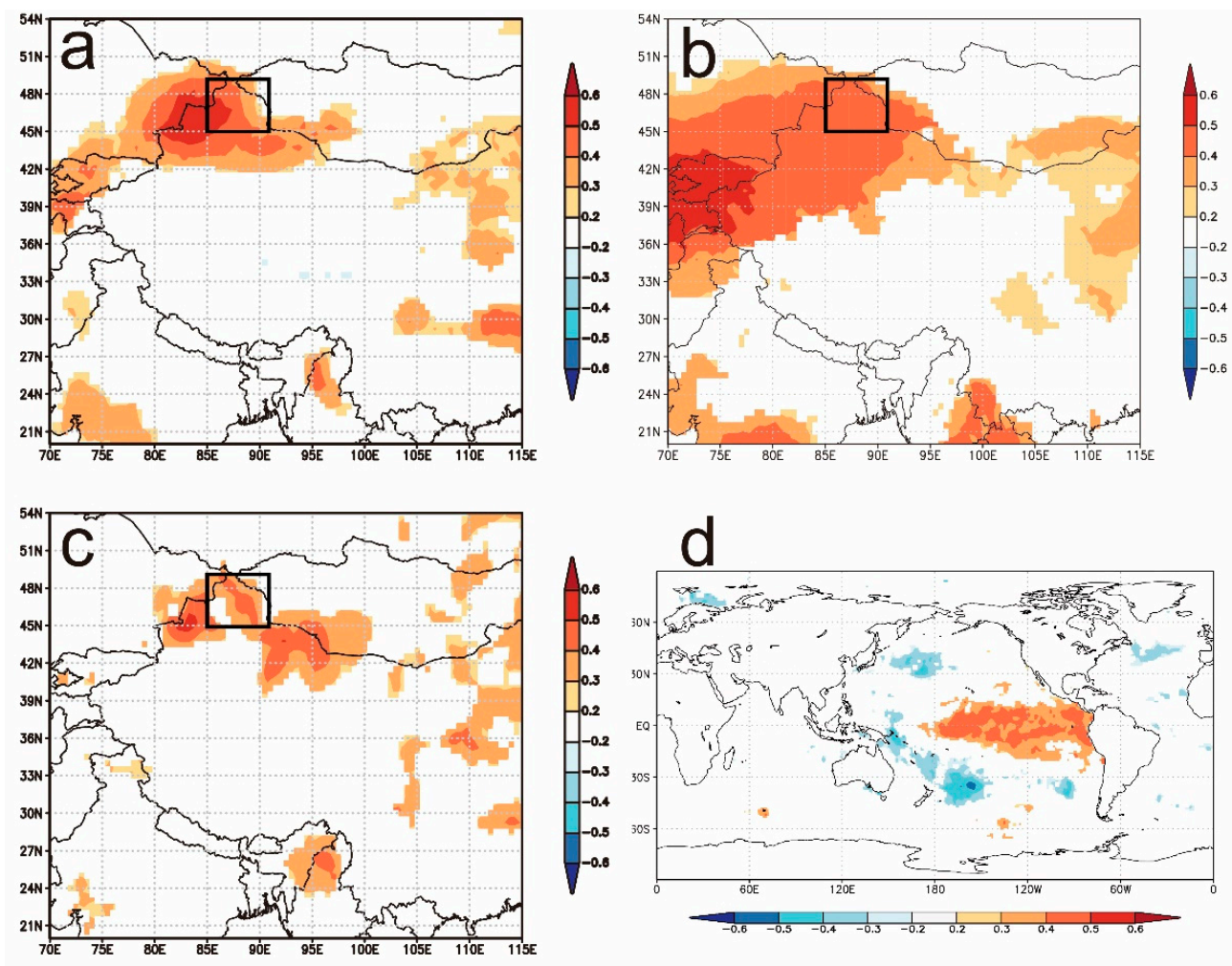

Figure 6. Spatial correlation coefficients of July-October NINO3 index of the previous year and summer moisture indicators, including (a) precipitation, (b) SPEI1, and (c) scPDSI. Black rectangles are the study region. Subplot (d) is spatial correlation coefficients of summer Altai RH and July-October global sea surface temperature (SST) of the previous year. Only parts with $R$ value $<0.05$ are shown.

\section{Discussion}

\subsection{Regional Climate Trends, Fire Frequency, and Burned Area}

High drought severity can increase the aridity of fuels and elevate forest fire frequency and area burned [52-54]. Warming itself and the associated increase in drought stress, extreme hot events, and fire season length are supposed to raise the fire risk as well $[55,56]$. Global change-type drought, also termed as warming-induced drought stress, has largely contributed to the increase in burned area and fire risk over dry areas [54,57]. However, despite significant summer warming $\left(0.28 \pm 0.026^{\circ} \mathrm{C} /\right.$ decade $p<0.001$, Figure A2a), the trend of annual summer fire frequency is insignificant in Altai.

In this study, both coincidences of frequent fire and extremely dry years and the correlation analysis showed a significant connection between drought stress and fire occurrence in Altai (Figures 2 and 3), suggesting that the summer fire occurrence in the study region is mainly dominated by drought severity. Among the moisture indices used, scPDSI and SPEI1 showed a slight and significant wet trend (Figure A2b,d), whereas precipitation increased as well but in a statistically insignificant manner (Figure A2c).

The ambiguous fire frequency trend and largely reduced burned area could also be due to the significant moistening trend along with warming as well as the strong fire suppression efforts and greatly increased investment in fire prevention since 1987.

\subsection{Teleconnections of La Nina Events and Drought Stress in Altai}

The El Nino events, defined as anomalously high SST over the eastern tropical Pacific, can lead to subsequent warmer SSTs over the northwest Pacific and tropical Indian Oceans [58,59]. Anomalous warm SSTs can reduce the land-ocean thermal gradient, delay the onset of the East Asian summer monsoon (EASM) and South Asian summer monsoon (SASM), and weaken monsoon intensities [60,61]. 
Thus, El Nino is usually responsible for interannual drought stress and fire occurrence in many monsoonal regions [62-64].

In contrast to an El Nino-caused drought, we found that the dry conditions (low precipitation, SPEI1, and scPDSI) of Altai are significantly associated with previous La Nina events (low NINO3) (Figures 5 and 6). The close association of previous La Nina and low summer precipitation in the study region was reported and interpreted in a previous study [61], where it was found that a cooler Indian Ocean SST usually occurs months after La Nina events. Then, the South Asian High (SAH) is pushed northward, which leads to a barotropic high-pressure anomaly over Northwest China. The anomalous high pressure is responsible for the less precipitation in the study region [61]. The significant teleconnections between previous La Nina events and high drought severity/fire occurrence can provide important knowledge for long-term forest fire prediction in Altai.

\subsection{Comparison with ENSO's Impact in Other Studies}

Previous studies have shown that fire risk and severities in boreal forests are higher following El Nino events in Canada and Northeast China [26,45]. Moreover, fire activities of boreal forests are usually characterized by large multidecadal variabilities, which are modulated by long-term climate dynamics in the Pacific and Atlantic sectors, such as PDO and Atlantic Multidecadal Oscillation (AMO) $[26,45,47,48,65]$. For the first time, we have identified that fire occurrence of boreal forests is teleconnected with La Nina rather than El Nino. At an interannual timescale, El Nino events contribute to extremely warm and dry conditions and are responsible for more wildfires in many regions of the world [39-42,44], whereas La Nina-associated fires can only be found in a few regions, such as West America [36].

Author Contributions: Conceptualization, C.S.; methodology, C.S.; software, C.S.; validation, C.S., Y.L., and L.S.; formal analysis, C.S.; investigation, C.S.; resources, C.S.; data curation, Y.L.; writing-original draft preparation, C.S.; writing-review and editing, C.G. and Q.W.; visualization, C.S.; supervision, C.S.; project administration, C.S.; funding acquisition, C.S., Q.W., and L.S. All authors have read and agreed to the published version of the manuscript.

Funding: This research was funded by the National Key Research and Development Plan (2017YFD0600106) and the Natural Science Foundation of China (31971667, 31570645 and 31660210).

Acknowledgments: The authors would like to acknowledge the Science and Technology Ministry and National Natural Science Foundation of China for their financial support as part of the statutory works.

Conflicts of Interest: The authors declare no conflict of interest.

\section{Appendix A}

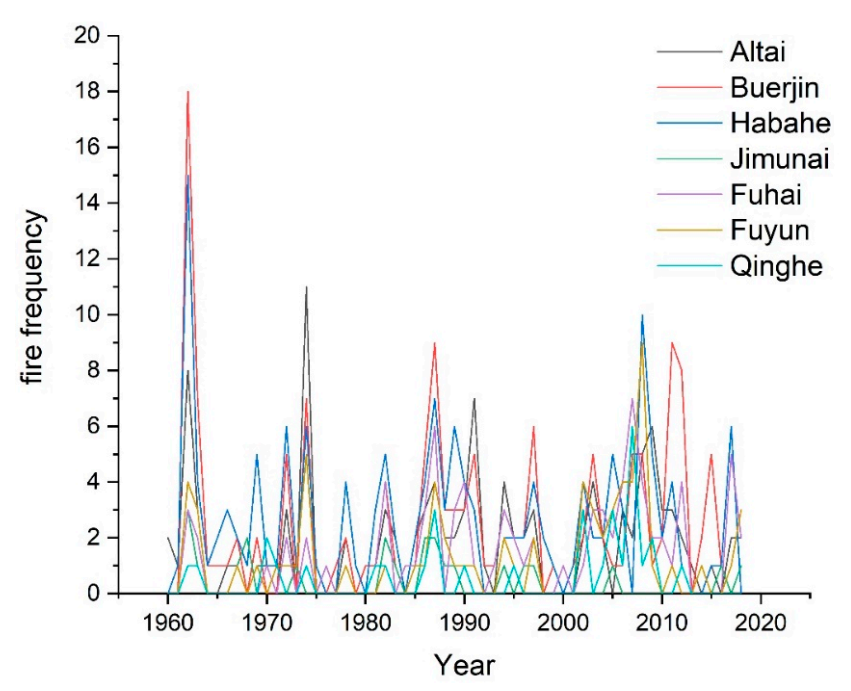

Figure A1. Summer forest fire frequency of the seven counties of Altai Prefecture. 


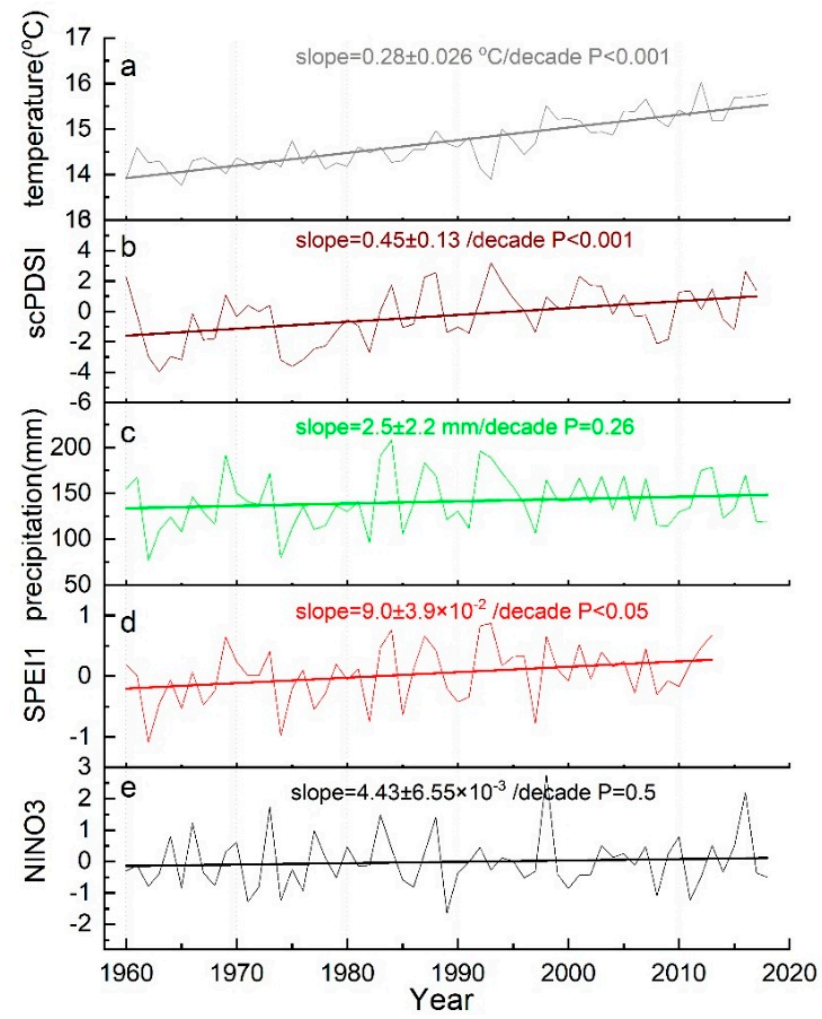

Figure A2. Summer climate trend over the study region, including (a) temperature, (b) scPDSI, (c) precipitation, (d) SPEI1, and (e) July-October NINO3 index of the previous year.

\section{References}

1. Jones, P.D.; New, M.; Parker, D.E.; Martin, S.; Rigor, I.G. Surface air temperature and its changes over the past 150 years. Rev. Geophys. 1999, 37, 173-199. [CrossRef]

2. Screen, J.A.; Simmonds, I. The central role of diminishing sea ice in recent Arctic temperature amplification. Nature 2010, 464, 1334-1337. [CrossRef] [PubMed]

3. Pepin, N.; Bradley, R.S.; Diaz, H.F.; Baraer, M.; Caceres, E.B.; Forsythe, N.; Fowler, H.; Greenwood, G.; Hashmi, M.Z.; Liu, X.D.; et al. Elevation-dependent warming in mountain regions of the world. Nat. Clim. Chang. 2015, 5, 424-430.

4. Kelly, R.; Chipman, M.L.; Higuera, P.E.; Stefanova, I.; Brubaker, L.B.; Hu, F.S. Recent burning of boreal forests exceeds fire regime limits of the past 10,000 years. Proc. Natl. Acad. Sci. USA 2013, 110, 13055-13060. [CrossRef] [PubMed]

5. Feurdean, A.; Florescu, G.; Tantau, I.; Vanniere, B.; Diaconu, A.C.; Pfeiffer, M.; Warren, D.; Hutchinson, S.M.; Gorina, N.; Gałka, M.; et al. Recent fire regime in the southern boreal forests of western Siberia is unprecedented in the last five millennia. Quat. Sci. Rev. 2020, 244, 106495. [CrossRef]

6. Price, C.; Rind, D. Possible implications of global climate change on global lightning distributions and frequencies. J. Geophys. Res. 1994, 99, 10823. [CrossRef]

7. Romps, D.M.; Seeley, J.T.; Vollaro, D.; Molinari, J. Projected increase in lightning strikes in the United States due to global warming. Science 2014, 346, 851-854. [CrossRef]

8. Veraverbeke, S.; Rogers, B.M.; Goulden, M.L.; Jandt, R.R.; Miller, C.E.; Wiggins, E.B.; Randerson, J.T. Lightning as a major driver of recent large fire years in North American boreal forests. Nat. Clim. Chang. 2017, 7, 529. [CrossRef]

9. Hanes, C.C.; Wang, X.; Jain, P.; Parisien, M.; Little, J.M.; Flannigan, M.D. Fire-regime changes in Canada over the last half century. Can. J. For. Res. 2019, 49, 256-269. [CrossRef]

10. Westerling, A.L. Increasing western US forest wildfire activity: Sensitivity to changes in the timing of spring. Philos. Trans. R. Soc. B 2016, 371, 20150175. [CrossRef] 
11. Westerling, A.L.; Hidalgo, H.G.; Cayan, D.R.; Swetnam, T.W. Warming and earlier spring increase western US forest wildfire activity. Science 2006, 313, 940-943. [CrossRef] [PubMed]

12. Portier, J.; Gauthier, S.; Leduc, A.; Arseneault, D.; Bergeron, Y. Fire Regime along Latitudinal Gradients of Continuous to Discontinuous Coniferous Boreal Forests in Eastern Canada. Forests 2016, 7, 211. [CrossRef]

13. Gonzalez, M.E.; Gomez-Gonzalez, S.; Lara, A.; Garreaud, R.; Diaz-Hormazabal, I. The 2010-2015 Megadrought and its influence on the fire regime in central and south-central Chile. Ecosphere 2018, 9, e02300. [CrossRef]

14. Overpeck, J.T.; Rind, D.; Goldberg, R. Climate-induced changes in forest disturbance and vegetation. Nature 1990, 343, 51-53. [CrossRef]

15. Johnstone, J.F.; Hollingsworth, T.N.; Chapin, F.S.I.; Mack, M.C. Changes in fire regime break the legacy lock on successional trajectories in Alaskan boreal forest. Glob. Chang. Biol. 2010, 16, 1281-1295. [CrossRef]

16. Bond-Lamberty, B.; Peckham, S.D.; Ahl, D.E.; Gower, S.T. Fire as the dominant driver of central Canadian boreal forest carbon balance. Nature 2007, 450, 89. [CrossRef]

17. Walker, X.J.; Baltzer, J.L.; Cumming, S.G.; Day, N.J.; Ebert, C.; Goetz, S.; Johnstone, J.F.; Potter, S.; Rogers, B.M.; Schuur, E.A.G.; et al. Increasing wildfires threaten historic carbon sink of boreal forest soils. Nature 2019, $572,520$. [CrossRef]

18. Randerson, J.T.; Liu, H.; Flanner, M.G.; Chambers, S.D.; Jin, Y.; Hess, P.G.; Pfister, G.; Mack, M.C.; Treseder, K.K.; Welp, L.R.; et al. The impact of boreal forest fire on climate warming. Science 2006, 314, 1130-1132. [CrossRef]

19. Oris, F.; Asselin, H.; Ali, A.A.; Finsinger, W.; Bergeron, Y. Effect of increased fire activity on global warming in the boreal forest. Environ. Rev. 2014, 22, 206-219. [CrossRef]

20. Van der Werf, G.R.; Randerson, J.T.; Giglio, L.; van Leeuwen, T.T.; Chen, Y.; Rogers, B.M.; Mu, M.; van Marle, M.J.E.; Morton, D.C.; Collatz, G.J.; et al. Global fire emissions estimates during 1997-2016. Earth Syst. Sci. Data 2017, 9, 697-720. [CrossRef]

21. Turetsky, M.R.; Kane, E.S.; Harden, J.W.; Ottmar, R.D.; Manies, K.L.; Hoy, E.; Kasischke, E.S. Recent acceleration of biomass burning and carbon losses in Alaskan forests and peatlands. Nat. Geosci. 2011, 4, 27-31. [CrossRef]

22. Westerling, A.L.; Turner, M.G.; Smithwick, E.A.H.; Romme, W.H.; Ryan, M.G. Continued warming could transform Greater Yellowstone fire regimes by mid-21st century. Proc. Natl. Acad. Sci. USA 2011, 108, 13165-13170. [CrossRef]

23. Flannigan, M.; Cantin, A.S.; de Groot, W.J.; Wotton, M.; Newbery, A.; Gowman, L.M. Global wildland fire season severity in the 21st century. For. Ecol. Manag. 2013, 294, 54-61. [CrossRef]

24. Jolly, W.M.; Cochrane, M.A.; Freeborn, P.H.; Holden, Z.A.; Brown, T.J.; Williamson, G.J.; Bowman, D.M.J.S. Climate-induced variations in global wildfire danger from 1979 to 2013. Nat. Commun. 2015, 6, 7537. [CrossRef] [PubMed]

25. Schoennagel, T.; Veblen, T.T.; Romme, W.H.; Sibold, J.S.; Cook, E.R. Enso and pdo variability affect drought-induced fire occurrence in Rocky Mountain subalpine forests. Ecol. Appl. 2005, 15, 2000-2014. [CrossRef]

26. Krishnamurthy, L.; Krishnamurthy, V. Influence of PDO on South Asian summer monsoon and monsoonENSO relation. Clim. Dynam. 2014, 42, 2397-2410. [CrossRef]

27. Yao, Q.; Brown, P.M.; Liu, S.; Rocca, M.E.; Trouet, V.; Zheng, B.; Chen, H.; Li, Y.; Liu, D.; Wang, X. Pacific-Atlantic Ocean influence on wildfires in northeast China (1774 to 2010). Geophys. Res. Lett. 2017, 44, 1025-1033. [CrossRef]

28. Gershunov, A.; Barnett, T.P. ENSO influence on intraseasonal extreme rainfall and temperature frequencies in the contiguous United States: Observations and model results. J. Clim. 1998, 11, 3062-3065. [CrossRef]

29. Lluch-Cota, D.B.; Wooster, W.S.; Hare, S.R. Sea surface temperature variability in coastal areas of the Northeastern Pacific related to the El Nino-Southern Oscillation and the Pacific Decadal Oscillation. Geophys. Res. Lett. 2001, 28, 2029-2032. [CrossRef]

30. Wu, R.; Yang, S.; Liu, S.; Sun, L.; Lian, Y.; Gao, Z. Changes in the relationship between Northeast China summer temperature and ENSO. J. Geophys. Res. Atmos. 2010, 115, D21107. [CrossRef]

31. McCabe, G.J.; Palecki, M.A.; Betancourt, J.L. Pacific and Atlantic Ocean influences on multidecadal drought frequency in the United States. Proc. Natl. Acad. Sci. USA 2004, 101, 4136-4141. [CrossRef] [PubMed]

32. Mo, K.C.; Schemm, J.E.; Yoo, S. Influence of ENSO and the Atlantic Multidecadal Oscillation on Drought over the United States. J. Clim. 2009, 22, 5962-5982. [CrossRef] 
33. Wen, N.; Liu, Z.; Li, L. Direct ENSO impact on East Asian summer precipitation in the developing summer. Clim. Dynam. 2019, 52, 6799-6815. [CrossRef]

34. Timmermann, A.; Oberhuber, J.; Bacher, A.; Esch, M.; Latif, M.; Roeckner, E. Increased El Nino frequency in a climate model forced by future greenhouse warming. Nature 1999, 398, 694-697. [CrossRef]

35. Cai, W.; Borlace, S.; Lengaigne, M.; van Rensch, P.; Collins, M.; Vecchi, G.; Timmermann, A.; Santoso, A.; McPhaden, M.J.; Wu, L.; et al. Increasing frequency of extreme El Nino events due to greenhouse warming. Nat. Clim. Chang. 2014, 4, 111-116. [CrossRef]

36. Cai, W.; Wang, G.; Santoso, A.; McPhaden, M.J.; Wu, L.; Jin, F.; Timmermann, A.; Collins, M.; Vecchi, G.; Lengaigne, M.; et al. Increased frequency of extreme La Nina events under greenhouse warming. Nat. Clim. Chang. 2015, 5, 132-137. [CrossRef]

37. Sibold, J.S.; Veblen, T.T. Relationships of subalpine forest fires in the Colorado Front Range with interannual and multidecadal-scale climatic variation. J. Biogeogr. 2006, 33, 833-842. [CrossRef]

38. Schoennagel, T.; Veblen, T.T.; Kulakowski, D.; Holz, A. Multidecadal climate variability and climate interactions affect subalpine fire occurrence, Western Colorado (USA). Ecology 2007, 88, 2891-2902. [CrossRef]

39. Sherriff, R.L.; Veblen, T.T. Variability in fire-climate relationships in ponderosa pine forests in the Colorado Front Range. Int. J. Wildland Fire 2008, 17, 50-59. [CrossRef]

40. Tian, X.; Shu, L.; Ali, F. The Affection of ENSO and Macula on Forest Fires in China. World For. Res. 2003, 16, $22-25$.

41. Van der Werf, G.R.; Randerson, J.T.; Collatz, G.J.; Giglio, L.; Kasibhatla, P.S.; Arellano, A.F.; Olsen, S.C.; Kasischke, E.S. Continental-scale partitioning of fire emissions during the 1997 to $2001 \mathrm{El}$ Nino/La Nina period. Science 2004, 303, 73-76. [CrossRef] [PubMed]

42. Hessl, A.E.; McKenzie, D.; Schellhaas, R. Drought and Pacific Decadal Oscillation linked to fire occurrence in the inland Pacific Northwest. Ecol. Appl. 2004, 14, 425-442. [CrossRef]

43. Margolis, E.Q.; Swetnam, T.W. Historical fire-climate relationships of upper elevation fire regimes in the southwestern United States. Int. J. Wildland Fire 2013, 22, 588-598. [CrossRef]

44. Power, S.; Casey, T.; Folland, C.; Colman, A.; Mehta, V. Inter-decadal modulation of the impact of ENSO on Australia. Clim. Dynam. 1999, 15, 319-324. [CrossRef]

45. Mariani, M.; Fletcher, M.S.; Holz, A.; Nyman, P. ENSO controls interannual fire activity in southeast Australia. Geophys. Res. Lett. 2016, 43, 10891-10900. [CrossRef]

46. Siegert, F.; Ruecker, G.; Hinrichs, A.; Hoffmann, A.A. Increased damage from fires in logged forests during droughts caused by El Nino. Nature 2001, 414, 437-440. [CrossRef]

47. Macias-Fauria, M.; Johnson, E.A. Large-scale climatic patterns control large lightning fire occurrence in Canada and Alaska forest regions. J. Geophys. Res. Biogeosci. 2006, 111, G04008. [CrossRef]

48. Macias-Fauria, M.; Johnson, E.A. Climate and wildfires in the North American boreal forest. Philos. Trans. R. Soc. B Biol. Sci. 2008, 363, 2317-2329. [CrossRef]

49. Meyn, A.; Taylor, S.W.; Flannigan, M.D.; Thonicke, K.; Cramer, W. Relationship between fire; climate oscillations, and drought in British Columbia, Canada, 1920-2000. Glob. Chang. Biol. 2010, 16, 977-989. [CrossRef]

50. Harvey, J.E.; Smith, D.J. Interannual climate variability drives regional fires in west central British Columbia, Canada. J. Geophys. Res. Biogeosci. 2017, 122, 1759-1774. [CrossRef]

51. Monks, S.A.; Arnold, S.R.; Chipperfield, M.P. Evidence for El Nino-Southern Oscillation (ENSO) influence on Arctic CO interannual variability through biomass burning emissions. Geophys. Res. Lett. 2012, 39, L14804. [CrossRef]

52. Russo, A.; Gouveia, C.M.; Pascoa, P.; DaCamara, C.C.; Sousa, P.M.; Trigo, R.M. Assessing the role of drought events on wildfires in the Iberian Peninsula. Agric. For. Meteorol. 2017, 237, 50-59. [CrossRef]

53. Taufik, M.; Torfs, P.J.J.F.; Uijlenhoet, R.; Jones, P.D.; Murdiyarso, D.; Van Lanen, H.A.J. Amplification of wildfire area burnt by hydrological drought in the humid tropics. Nat. Clim. Chang. 2017, 7, 428. [CrossRef]

54. Kodandapani, N.; Parks, S.A. Effects of drought on wildfires in forest landscapes of the Western Ghats, India. Int. J. Wildland Fire 2019, 28, 431-444. [CrossRef]

55. Crockett, J.L.; Westerling, A.L. Greater Temperature and Precipitation Extremes Intensify Western US Droughts, Wildfire Severity; and Sierra Nevada Tree Mortality. J. Clim. 2018, 31, 341-354. [CrossRef] 
56. Ruffault, J.; Curt, T.; Martin-StPaul, N.K.; Moron, V.; Trigo, R.M. Extreme wildfire events are linked to global-change-type droughts in the northern Mediterranean. Nat. Hazard Earth Syst. Sci. 2018, 18, 847-856. [CrossRef]

57. Gudmundsson, L.; Rego, F.C.; Rocha, M.; Seneviratne, S.I. Predicting above normal wildfire activity in southern Europe as a function of meteorological drought. Environ. Res. Lett. 2014, 9, 084008. [CrossRef]

58. Chan, J.; Zhou, W. PDO, ENSO and the early summer monsoon rainfall over south China. Geophys. Res. Lett. 2005, 32, L08810. [CrossRef]

59. Yang, J.; Liu, Q.; Xie, S.; Liu, Z.; Wu, L. Impact of the Indian Ocean SST basin mode on the Asian summer monsoon. Geophys. Res. Lett. 2007, 34, L02708. [CrossRef]

60. Ju, J.H.; Slingo, J. The Asian Summer Monsoon and ENSO. Q. J. R. Meteorol. Soc. 1995, 121, $1133-1168$. [CrossRef]

61. Wang, B.; Wu, R.G.; Lau, K.M. Interannual variability of the Asian summer monsoon: Contrasts between the Indian and the western North Pacific-east Asian monsoons. J. Clim. 2001, 14, 4073-4090. [CrossRef]

62. Cleary, D.; Grill, A. Butterfly response to severe ENSO-induced forest fires in Borneo. Ecol. Entomol. 2004, 29, 666-676. [CrossRef]

63. Lu, B.; Li, H.; Wu, J.; Zhang, T.; Liu, J.; Liu, B.; Chen, Y.; Baishan, J. Impact of El Nino and Southern Oscillation on the summer precipitation over Northwest China. Atmos. Sci. Lett. 2019, 20, e928. [CrossRef]

64. Novitasari, N.; Sujono, J.; Harto, S.; Maas, A.; Jayadi, R. Drought Index for Peatland Wildfire Management in Central Kalimantan; Indonesia During El Nino Phenomenon. J. Disaster Res. 2019, 14, 939-948. [CrossRef]

65. Mori, A.S. Climatic variability regulates the occurrence and extent of large fires in the subalpine forests of the Canadian Rockies. Ecosphere 2011, 2, 1-20. [CrossRef]

(C) 2020 by the authors. Licensee MDPI, Basel, Switzerland. This article is an open access article distributed under the terms and conditions of the Creative Commons Attribution (CC BY) license (http://creativecommons.org/licenses/by/4.0/). 